\title{
Assessing the Impact of Transition from Face-to-Face to Online Instruction on Team Cooperation
}

\section{Ms. Aparajita Jaiswal, Purdue University, West Lafayette}

Aparajita Jaiswal is a Ph.D. student at Purdue Polytechnic at Purdue University, West Lafayette. Her research interests are in data science education, computational thinking, student engagement and motivation in active learning environments.

\section{Dr. Paul J. Thomas, Purdue University, West Lafayette}

Paul Thomas is a graduate of the $\mathrm{PhD}$ in Technology program at Purdue University. His research interests are in software modeling, gamification, and active learning.

Dr. Tugba Karabiyik, Purdue University, West Lafayette

Dr. Tugba Karabiyik is an interdisciplinary postdoctoral researcher at Purdue University. She holds an MS and Ph.D. degrees both from Florida State University. Before her appointment at Purdue University, she worked as a lecturer and Visiting Assistant Professor at Sam Houston State University for three years. Her research interests include data-driven decision making through data visualizations, economic decision making in engineering design, and applications of game-theoretic and agent-based modeling in computational science, finance, information technology, and engineering fields. Dr. Karabiyik is an expert in conflict, competition, strategic decision-making. She has been working on developing and applying mathematical and statistical models in various domains, including educational settings.

\section{Dr. Viranga Perera, Purdue University, West Lafayette}

Viranga Perera is a postdoctoral researcher at Purdue University. He obtained his Ph.D. from Arizona State University in 2017. His research interests are in STEM education and planetary physics.

\section{Dr. Alejandra J. Magana, Purdue University, West Lafayette}

Alejandra Magana is The W.C. Furnas Professor in Enterprise Excellence in the Department of Computer and Information Technology and an affiliated faculty at the School of Engineering Education at Purdue University. She holds a B.E. in Information Systems, a M.S. in Technology, both from Tec de Monterrey; and a M.S. in Educational Technology and a Ph.D. in Engineering Education from Purdue University. Her research is focused on identifying how model-based cognition in STEM can be better supported by means of expert technological and computing tools such as cyber-physical systems, visualizations, and modeling and simulation tools. 


\title{
Assessing the Impact of Transition from Face-to-Face to Online Instruction on Team Cooperation
}

\begin{abstract}
Teamwork is an important skill valued by corporate employers across the globe. As such, it is crucial for students to learn teamwork for the purpose of securing a job and performing well in corporate environments. In addition to certain technical skills, essential 21 st-century skills include communication, collaboration, critical thinking, and creativity. A well-known learning theory that helps students learn these skills is cooperative learning. Cooperative learning posits that when students collaborate within teams to solve complex problems, their creativity and critical thinking skills are improved as a result. Implementing cooperative learning in the past several months has been challenging due to the COVID-19 pandemic. The sudden shift from face-to-face to online instruction, has left a void for newer pedagogical approaches to teach teamwork. In this full paper, we investigate the impact of cooperative learning during the Spring 2020 semester by studying team retrospectives written by students enrolled in a system analysis and design course.

The pedagogical foundation for the system analysis and design course was cooperative learning. The course required students to work in teams to develop a software prototype. The project was divided into four milestones and each team was required to submit a team retrospective detailing overall planning, task allocation, group processes, and strategies for improvement. The first two milestones were completed during face-to-face instruction, while teams met online for the last two milestones due to the shift to online instruction. To investigate team effectiveness, a rubric based on the Goals, Roles, Processes and Interpersonal relations (GRPI) model of team effectiveness was created and team retrospectives were scored using that rubric. We used a mixed-method approach to explore the following research questions: 1) What was the impact on team effectiveness when instruction changed from face-to-face to online due to the COVID-19 pandemic? 2)What strategies were adopted by teams to navigate the sudden change in instruction? To address the first research question, we performed inferential statistics to compare the impact of team effectiveness between face-to-face and online instruction. To address the second research question, we conducted a thematic analysis to understand the qualitative differences of team effectiveness for face-to-face and online instruction. Our results demonstrate a significant increase in teamwork effectiveness for online instruction. In addition, our thematic analysis shows particular strategies adopted by teams that led to improved team effectiveness in the online instruction environment.
\end{abstract}

\section{Introduction}

Professionals working in the Information Technology (IT) sector are expected to be proficient with domain-specific technical skills, while also being able to solve problems by working with their peers, users, and clients [1], [2]. As such, IT professionals are required to be proficient with social skills such as communication and teamwork [3]. Furthermore, competence in writing and proficiency in management skills are described as critical to being successful as an IT professional [4]. To address these needs, cooperative learning pedagogies have been implemented in higher education settings to promote proficiency in problem-solving skills, communication, and teamwork [5], [6]. Cooperative learning implemented through small group 
learning has been largely successful in STEM courses in promoting academic achievement and student perceptions of self-efficacy [7], [8]. A prominent model used to characterize team development in various settings is the Tuckman model. It lends itself well to cooperative learning and proposes a series of stages that teams must overcome to function effectively [9]. Courses should ideally be structured in a manner that implements the tenets of cooperative learning [5] while allowing teams to organically navigate the different stages of team development.

Presently the COVID-19 pandemic is having a tangible and substantial impact on education globally [24]. Educational institutions across the world, ranging from elementary schools to universities, were forced to close unexpectedly [25]. A survey conducted by the International Association of Universities (IAU) indicated that more than half of the 424 institutions (that were contacted) were forced to stop all in-person campus activities [10]. To minimize disruption to students, educational institutions are transitioning to online instruction [26]. While online education has been around for some time, with several universities offering hybrid courses or even fully online degrees [27], the circumstances in the Spring 2020 semester were unprecedented due to the sudden and unexpected cancelation of in-person classes. Course instructors were required to transition course material, that was originally designed to be delivered in-person, to a fully online setting. This rapid change in instruction introduced additional challenges for students involved in team projects since they could no longer meet with team members in-person. Naturally, there is a gap in the literature on the COVID-19 pandemic and its impact on team effectiveness in cooperative learning environments that we aim to address in this work.

While there have been several inquiries into cooperative learning, online education, and team effectiveness, none have investigated the impact of a sudden instructional shift on team effectiveness in a cooperative learning environment. This study aims to address this gap by investigating the impact of cooperative learning on student teams enrolled in a system analysis and design course during the Spring 2020 semester. The first nine weeks involved in-person instruction, and the last seven weeks were conducted completely online. We used the GRPI framework to assess student team effectiveness as they progressed through different milestones. Our research questions were: 1) What was the impact on team effectiveness when instruction changed from face-to-face to online instruction due to the COVID-19 pandemic? 2) What strategies were adopted by teams to navigate the sudden change in instruction?

\section{Background}

The Tuckman model describes team development as a series of stages; nevertheless, it does not assess team effectiveness. As such, we use the GRPI framework since it was developed to measure team effectiveness. The framework and its application to cooperative learning environments will be discussed below. Additionally, the impact of the COVID-19 pandemic on educational institutions will also be explored. 


\section{Cooperative learning}

Cooperative learning is a pedagogical strategy where learners work in small groups to achieve a specific goal [11]. The origins of cooperative learning lie in social interdependence theory, which states that the intensity of interactions between individuals in a social setting determines the effectiveness of the outcome. Cooperative learning involves promoting learning and providing recognition as a group instead of an individual [12]. Adopting cooperative learning has often shown improvement in students' academic achievement, along with improvement in selfesteem, attitudes towards learning, and the ability to work in teams [8].

\section{Tuckman model}

The Tuckman model is by far the most prevalent approach in the context of a group or team development [13]. It was first developed in 1965 based on analyses of groups in therapy and laboratory settings [14]. The Tuckman model consists of four stages that must be sequentially negotiated for a team or group to achieve effectiveness [9]. The four stages are as follows:

1. Forming: The forming stage is centered around task orientation as well as establishing ground rules for interpersonal communication and processes for completing tasks.

2. Storming: The storming stage is characterized by interpersonal conflict or open hostility. Team members often exhibit emotional responses to tasks.

3. Norming: The norming stage follows the storming stage and is characterized by team cohesion. Team members have identified the most effective ways to complete tasks.

4. Performing: In the performing stage, team members exhibit flexibility in terms of roles adopted and tasks taken up for completion.

Ideally, a cooperative learning environment will facilitate progression of teams through these stages. The model also suggests that team effectiveness improves over time as teams navigate sequentially through the stages.

\section{GRPI framework}

The GRPI (Goals, Roles, Processes, Interpersonal relations) framework has been used to measure team effectiveness in a variety of sectors [15], [16]. The framework proposes that team effectiveness can be measured as an aggregate of how teams define their goals, allocate roles, establish workflow processes, and define how team members will communicate, collaborate, and manage conflict [17]. The GRPI framework has been successfully used to measure team effectiveness [18] and conflict resolution ability [19]. The GRPI framework has specifically been used to develop rubrics that assess team effectiveness in an educational setting [20]. It has further allowed for a better understanding of team dynamics [21] and the effect of team commitment on trust between members [22]. Crucially, the model has also been used in a study to evaluate the effectiveness of virtual teams [23]. For this study, rubrics developed by Karabiyik et al. were used to evaluate team effectiveness in both face-to-face and online settings [20]. 


\section{Methods}

\section{Participants and Context}

This study was implemented in the Spring 2020 semester at a Midwestern university. The study cohort was 135 undergraduate students enrolled in a systems analysis and design course. All students were in their second year or later. Over $80 \%$ of students were either pursuing a Computer and Information Technology major or minor. Students were required to complete an introductory systems development course as a prerequisite for this course. Students were also required to have some experience with computer programming, either through coursework or practical experience. Students worked on a project in teams of five. The project was divided into four milestones. The main goal was to create a final solution through iteration that incorporated feedback.

\section{Learning Design}

The first nine weeks of the class were delivered face-to-face, which included submitting the first two milestones. Due to the COVID-19 pandemic, classes were shifted online for the remaining seven weeks. Thus, the last two milestones were submitted online. The primary learning outcome was developing teamwork skills while working in a project-based learning environment. By working on the project, students applied their conceptual knowledge to model requirements to build a prototype. There were four milestones, and the first two were submitted during the faceto-face portion of the class. Teams also submitted the first two iterations of their functional prototype. Milestones 3 and 4 were submitted during the last seven weeks during the fully online portion of the course. Teams also delivered functional prototypes that incorporated all requirements, along with their final presentation. For the first nine weeks, teams communicated and worked face-to-face. During the last seven weeks, they used online tools (e.g., GroupMe, Chat Me, and Zoom) to communicate.

\section{Research Design}

Here we used a mixed-method approach [28] to analyze the impact of the instructional change (i.e., face-to-face to online) on team effectiveness. This study includes the sequential use of qualitative and quantitative research methods for analyzing data [29].

\section{Data Collection}

Data used for this work are written team retrospectives. Students were required to submit team retrospectives at the end of each milestone. Team retrospectives were drafted by team members based on questions listed in Table 1, which were adopted from Karabiyik et al. [20]. Table 1 below represents the mapping between the GRPI framework and team retrospective questions. We received human subjects research approval from the Institutional Review Board (IRB). 
Table 1: Mapping of GRPI framework with Team Retrospective Questions (Adopted from [20])

\begin{tabular}{|c|c|c|}
\hline Theme & Definition & Team Retrospective Questions \\
\hline Goals & $\begin{array}{l}\text { Explanation of planning or } \\
\text { overall vision for the current } \\
\text { milestone. }\end{array}$ & $\begin{array}{l}\text { - How did you plan the } \\
\text { organization of work for the } \\
\text { milestone? }\end{array}$ \\
\hline Roles & $\begin{array}{l}\text { All team members must know } \\
\text { what part they play, what is } \\
\text { expected, and how they are held } \\
\text { accountable and responsible. }\end{array}$ & $\begin{array}{l}\text { - What were the team } \\
\text { members' roles? } \\
\text { - How were activities assigned } \\
\text { to each team member, and } \\
\text { what was the justification for } \\
\text { that? }\end{array}$ \\
\hline Processes & $\begin{array}{l}\text { Explanation about procedures } \\
\text { that the team has to follow, in } \\
\text { terms of workflow or review, } \\
\text { for current milestones or } \\
\text { improvements to be made for } \\
\text { future milestones. }\end{array}$ & $\begin{array}{l}\text { What are areas or sections of } \\
\text { the milestone that you just } \\
\text { completed you think could be } \\
\text { improved? } \\
\text { - What are the aspects you } \\
\text { think can be done better for } \\
\text { the next milestone in terms of } \\
\text { team performance? } \\
\text { - What are the possible } \\
\text { concerns? } \\
\text { - What do you think as a team } \\
\text { was particularly good about } \\
\text { the milestone you just } \\
\text { completed? }\end{array}$ \\
\hline $\begin{array}{l}\text { Interpersonal } \\
\text { Relationships }\end{array}$ & $\begin{array}{l}\text { Explanation about quality of } \\
\text { communication and } \\
\text { collaboration among team } \\
\text { members, any reference to } \\
\text { communication platform, team } \\
\text { participation, conflict } \\
\text { management, and resolution. }\end{array}$ & $\begin{array}{l}\text { How was the communication } \\
\text { handled among team } \\
\text { members? } \\
\text { What aspects of the team } \\
\text { coordination/collaboration } \\
\text { went well in this milestone? } \\
\text { What aspects of the team } \\
\text { coordination/collaboration } \\
\text { went wrong in this milestone? }\end{array}$ \\
\hline
\end{tabular}




\section{Rubrics and Data Analysis}

The rubric for this study was adopted from Karabiyik et al. [20]. Table 2 below shows the rubric used for this work. Two raters scored all 27 team retrospectives based on the GRPI rubric. We used the Pearson correlation coefficient to calculate interrater reliability [30]. The correlation between the two raters was 0.90, suggesting a high degree of agreement between the raters. We calculated descriptive statistics including mean, median, and standard deviation for both face-toface and online instruction. Face-to-face instruction refers to the combined average of the GRPI scores for Milestones 1 and 2, while online instruction refers to the combined average of the GRPI scores for Milestones 3 and 4 (see Table 3). Further, we used the Wilcoxon Signed Ranks test to identify any significant statistical difference in team effectiveness between face-to-face and online instruction. Additionally, we conducted a thematic analysis, which demonstrated an improvement in team effectiveness when instruction transitioned from face-to-face to online.

Table 2: Rubric for the GRPI Framework

(Adopted from [20])

\begin{tabular}{|c|c|c|c|}
\hline Criterion & $\mathbf{0}$ & 1 & 2 \\
\hline Goals & $\begin{array}{l}\text { Did not address the } \\
\text { overall plan for the } \\
\text { current milestone in } \\
\text { terms of goals and/or } \\
\text { organization }\end{array}$ & $\begin{array}{l}\text { Addressed goals and } \\
\text { organization of the } \\
\text { team in an insufficient } \\
\text { manner }\end{array}$ & $\begin{array}{l}\text { Comprehensively } \\
\text { addressed the goals and } \\
\text { organization of the team }\end{array}$ \\
\hline Roles & $\begin{array}{l}\text { Did not delineate the } \\
\text { roles and } \\
\text { responsibilities of } \\
\text { team members }\end{array}$ & $\begin{array}{l}\text { Vaguely defined the } \\
\text { roles and } \\
\text { responsibilities of } \\
\text { some team members } \\
\text { or did so for all team } \\
\text { members but was } \\
\text { lacking clarity }\end{array}$ & $\begin{array}{l}\text { Explicitly delineated } \\
\text { roles and } \\
\text { responsibilities of every } \\
\text { team member }\end{array}$ \\
\hline Processes & $\begin{array}{l}\text { No detailed } \\
\text { explanation for } \\
\text { procedures the team } \\
\text { has to follow }\end{array}$ & $\begin{array}{l}\text { Vaguely defined } \\
\text { procedures for the } \\
\text { team to follow }\end{array}$ & $\begin{array}{l}\text { Explicitly defined } \\
\text { procedures for the team } \\
\text { to follow }\end{array}$ \\
\hline $\begin{array}{l}\text { Interpersonal } \\
\text { Relationships }\end{array}$ & $\begin{array}{l}\text { Exhibited poor } \\
\text { quality of } \\
\text { communication and } \\
\text { collaboration }\end{array}$ & $\begin{array}{l}\text { Exhibited moderate } \\
\text { quality of } \\
\text { communication and } \\
\text { collaboration }\end{array}$ & $\begin{array}{l}\text { Exhibited excellent } \\
\text { quality of } \\
\text { communication and } \\
\text { collaboration }\end{array}$ \\
\hline
\end{tabular}




\section{Results}

Descriptive statistics of the GRPI scores are shown in Table 3. Our results demonstrate that students in the online instruction setting demonstrated higher mean scores for team effectiveness as compared to students in the face-to-face setting. We computed the median for each type of instruction as the aggregate median GRPI scores across all groups in each type of instruction.

Table 3: Descriptive Statistics for Face-to-Face and Online Instruction

\begin{tabular}{|c|c|c|c|}
\hline Type of Instruction & Mean & Median & SD \\
\hline Face-to-Face & 1.26 & 1.0 & 0.42 \\
\hline Online & 1.46 & 1.5 & 0.35 \\
\hline
\end{tabular}

Given that the data was ordinal, we used the Wilcoxon signed ranks test to determine if there were any significant statistical differences between face-to-face and online instruction. The Wilcoxon signed ranks test showed a statistically significant difference between the median GRPI scores of teams during online instruction (Median=1.5), compared to the same teams under face-to-face instruction (Median=1.0), $z=-3.29, p<0.01$. This suggests that teams were more effective during online instruction compared to face-to-face instruction.

We performed our thematic analysis based on the principles of Braun and Clarke [31]. The six steps that were followed for the thematic analysis were: (1) understanding the data, (2) generating initial codes, (3) looking out for themes, (4) reevaluating the generated themes, (5) defining and finalizing the themes, and (6) reporting the final themes. Two researchers independently coded the data and then discussed the codes. We calculated the Pearson correlation coefficient as a measure of agreement (i.e., inter-rater reliability) [30]. The correlation coefficient was 0.86 , suggesting a high degree of agreement between the raters. Themes that emerged are listed in Table 4.

Table 4: Themes, Definitions, and Student Quotes

\begin{tabular}{|l|l|l|}
\hline \multicolumn{1}{|c|}{ Theme } & \multicolumn{1}{|c|}{ Definition } & \multicolumn{1}{c|}{ Student Quote } \\
\hline $\begin{array}{l}\text { Online } \\
\text { Communication } \\
\text { Tools }\end{array}$ & $\begin{array}{l}\text { Students switched } \\
\text { to online resources } \\
\text { to communicate as } \\
\text { the course went } \\
\text { online }\end{array}$ & $\begin{array}{l}\text { "Normally the team would collaborate and } \\
\text { distribute work during class meetings, but due to } \\
\text { the COVID-19 global pandemic and isolation } \\
\text { orders all in-person work was stopped, and the } \\
\text { team switched to strictly virtual communication." }\end{array}$ \\
\hline Online Collaboration & $\begin{array}{l}\text { Students used } \\
\text { strategies to } \\
\text { collaborate online }\end{array}$ & $\begin{array}{l}\text { "While virtual communication is the most } \\
\text { convenient option available to the group during } \\
\text { this milestone the group overcame this }\end{array}$ \\
\hline
\end{tabular}




\begin{tabular}{|l|l|l|}
\hline effectively & $\begin{array}{l}\text { communication issue by diligently checking the } \\
\text { group message and Blackboard for class updates, } \\
\text { keeping each other accountable with reminders, } \\
\text { and finishing work by the set internal deadlines. } \\
\text { By practicing these actions, the team was able to } \\
\text { deliver the required work on time." }\end{array}$ \\
\hline Team Spirit & $\begin{array}{l}\text { Students kept their } \\
\text { spirits high even } \\
\text { after the sudden } \\
\text { transition }\end{array}$ & $\begin{array}{l}\text { "Despite not being in class, not receiving physical } \\
\text { instruction, not being on campus, and for some } \\
\text { group members packing up their entire lives and } \\
\text { moving back across the country, the team was } \\
\text { able to prioritize classwork and rise to the } \\
\text { challenge of completing the milestone on time." }\end{array}$ \\
\hline Strategies & $\begin{array}{l}\text { Students tracked } \\
\text { their strategies and } \\
\text { identified steps to } \\
\text { improve }\end{array}$ & $\begin{array}{l}\text { "As for future milestones, we believe it is } \\
\text { important for us to effectively spread the work of } \\
\text { the project evenly across the time period allotted } \\
\text { for each milestone. Time management is } \\
\text { definitely one of the aspects we need to improve } \\
\text { on as we move to an online version of the course } \\
\text { and face-to-face collaboration becomes } \\
\text { impossible. It is also important for us to keep in } \\
\text { contact and check-in on the progress of the } \\
\text { milestone more often as the due date approaches." }\end{array}$ \\
\hline
\end{tabular}

\section{Discussion}

In this work, we set out to answer two research questions on team effectiveness. Below we discuss each in turn.

What was the impact on team effectiveness when instruction changed from face-to-face to online due to the COVID-19 pandemic?

Our study found that team effectiveness improved during online instruction as compared to faceto-face instruction. This is shown in Table 3 and is statistically significant according to the Wilcoxon signed ranks test. There are several possible reasons why teams demonstrated a significant improvement in the effectiveness levels. Students being restricted to a certain location (e.g., their home) and having limited opportunities for social activities could have had a positive effect on their academics due to an added focus. However, those same circumstances may have had a negative effect on some students who had less time due to added household responsibilities and possible psychological and financial stressors due to the pandemic. Nevertheless, it is conceivable that teamwork improved as a result of the online environment. Since they could not meet in person, students may have had to be more diligent in communicating using online collaboration tools, which led to better team interactions. Table 5 shows a comparison of Team $\mathrm{H}$ discussing collaboration in the face-to-face and online setting. Team quotes in Table 5 provide 
evidence that online tools enabled better collaboration in the online instructional setting, as compared to the face-to-face setting. Nevertheless, it is too early to definitively state that it was solely the online mode of instruction that caused this improved team effectiveness.

Table 5: Team H quotes comparing Face-to-Face with Online Instruction

\begin{tabular}{|l|l|}
\hline \multicolumn{1}{|c|}{ Face-to-face } & \multicolumn{1}{c|}{ Online } \\
\hline $\begin{array}{l}\text { "Since everyone was busy, there was not } \\
\text { enough time for us to meet outside of class. I } \\
\text { think if we had more time to collaborate in } \\
\text { person, it would make it easier to complete } \\
\text { the milestone before the due date. It would } \\
\text { allow us to be on the same page when } \\
\text { working." }\end{array}$ & $\begin{array}{l}\text { "A few aspects that went well was that we } \\
\text { were all able to meet at different times } \\
\text { through Zoom. Having the ability to complete } \\
\text { tasks online was helpful when it is difficult to } \\
\text { meet in person even when every member is on } \\
\text { campus. Despite the fact of the changes } \\
\text { recently, we were able to transition pretty well } \\
\text { and did not have much impact on our } \\
\text { productivity." }\end{array}$ \\
\hline
\end{tabular}

Teamwork may have improved from face-to-face to online instruction due to several other factors. Most students in our cohort were in their second year. Thus, it is plausible that they may not have had much experience working well in teams. As such, our measured improvement may be due to their overall improvement as a result of learning to work effectively in teams. This aligns well with the Tuckman model, which suggests that people develop teamwork skills over time. Since online instruction occurred after face-to-face instruction, improvement in team effectiveness may be attributed to timing. Furthermore, the pandemic itself may have encouraged collaboration and helping behavior due to globally trying times.

What were the strategies adopted by the teams to navigate the sudden change in the instructions?

With the change to online instruction, students naturally shifted to using online collaboration tools to compensate for the lack of in-person interaction. This work suggests that students had little difficulty with online collaboration tools. In addition to those tools, students learned to identify strategies for improvement. As examples, they set their deadlines and held each other accountable. Table 6 shows a comparison of Team $\mathrm{K}$ discussing communication in the face-toface and online setting. Overall, students showed that they were able to successfully adapt to the online environment.

Table 6: Team K quotes comparing Face-to-Face with Online Instruction

\begin{tabular}{|l|l|}
\hline \multicolumn{1}{|c|}{ Face-to-face } & \multicolumn{1}{c|}{ Online } \\
\hline $\begin{array}{l}\text { "Initially, we struggled finding a time } \\
\text { that worked best for all of us. We } \\
\begin{array}{l}\text { overcame this challenge with extensive } \\
\text { examinations of our schedules. }\end{array}\end{array}$ & $\begin{array}{l}\text { "First, we have a team GroupMe group message for } \\
\text { general communication and reminders about due } \\
\text { dates. Second, we have a team Discord set up for } \\
\text { voice and video communication when working on }\end{array}$ \\
\hline
\end{tabular}


Additionally, we struggled to find an effective system to equally distribute work; however, after thorough communication, we agreed upon a system that worked for this milestone." critical work like sprints that requires more in-depth communication than just text. Third, we all have each other's Snapchats for direct messages and more urgent messages. All of these platforms combined help us effectively communicate as a team. Everyone responded as quickly as possible considering time zone differences when asked for a good time to work. Our Google Document was also set up well so that each group member knew exactly what part they had to do and every other group member could easily monitor the progress of the rest of the member."

\section{Implications for Teaching and Learning}

Our results have multiple implications for teaching and learning. Two prominent implications are: (1) Teachers should focus on creating a structured cooperative learning environment that helps students to mitigate unforeseen challenges. (2) Collaborative learning improves team effectiveness and team bonding. Our results reveal that focusing on the structured cooperative environment allowed students to collaborate and navigate the challenges of the COVID-19 pandemic and sudden instructional transition. The collaborative environment allowed students to develop an understanding among team members. Our results demonstrate that students learned to meet and execute tasks irrespective of time zone differences. This can be aided by instructional scaffolds to facilitate remote work.

\section{Conclusion and Limitations}

This study demonstrates that team effectiveness improved as students spent more time with each other over the semester. Our results also confirm that allowing students to collaborate helps them learn skills such as collaboration, cooperation, and accommodation. Student teams navigated the challenges of the COVID-19 pandemic as a group and completed their project deliverables even with challenges such as time zone differences. Students developed team cohesion as they met regularly during face-to-face instruction, which helped them collaborate better when instruction shifted online. One important point to note is that the study was an inquiry into effectiveness of team cooperation and not an academic performance; therefore, students' grades were not considered for our analyses. Our study has some limitations: (1) Results are based on student retrospectives containing the reflections of students regarding their teamwork experience. (2) We could not interview students, so all results are based on students' reflections of teamwork. Future work should explore this further with control groups to better identify if it is online instruction that lends itself to improved teamwork.

\section{References}

[1] K. S. Koong, L. C. Liu, and X. Liu, "A Study of the Demand for Information Technology Professionals in Selected Internet Job Portals," vol. 13, p. 9. 
[2] M. P. Sivitanides, J. R. Cook, R. B. Martin, B. A. Chiodo, and F. Landram, "Verbal Communication Skills Requirements for Information Systems Professionals," J. Inf. Syst. Educ., vol. 7, no. 1, p. 38, May 1995.

[3] J. L. Bailey and G. Stefaniak, "Preparing the information technology workforce for the new millennium," in Proceedings of the 2000 ACM SIGCPR conference on Computer personnel research - SIGCPR '00, Chicago, Illinois, United States, 2000, pp. 1-7, doi: $10.1145 / 333334.333336$

[4] M. Wilkins and C. Noll, "Revolutionary changes are occurring across the US and the world in information systems technology,” p. 7

[5] A. J. Magana, Y. Y. Seah, and P. Thomas, "Fostering Cooperative Learning with Scrum in a Semi- Capstone Systems Analysis and Design Course," vol. 29, p. 20, 2018.

[6] D. W. Johnson, R. T. Johnson, and K. A. Smith, "Cooperative Learning Returns to College What Evidence Is There That It Works?," Change Mag. High. Learn., vol. 30, no. 4, pp. 2635, Jul. 1998, doi: 10.1080/00091389809602629.

[7] G. S. Stump, J. C. Hilpert, J. Husman, W. Chung, and W. Kim, "Collaborative Learning in Engineering Students: Gender and Achievement," J. Eng. Educ., vol. 100, no. 3, pp. 475-497, Jul. 2011, doi: 10.1002/j.2168-9830.2011.tb00023.x.

[8] L. Springer, M. E. Stanne, and S. S. Donovan, "Effects of Small-Group Learning on Undergraduates in Science, Mathematics, Engineering, and Technology: A Meta-Analysis," p. 31.

[9] D. A. Bonebright, "40 years of storming: a historical review of Tuckman's model of small group development," Hum. Resour. Dev. Int., vol. 13, no. 1, pp. 111-120, Feb. 2010, doi: 10.1080/13678861003589099.

[10] G. Marinoni, H. Van't Land, and T. Jensen, "The impact of Covid-19 on higher education around the world," IAU Glob. Surv. Rep., 2020.

[11] D. W. Johnson and R. T. Johnson, Learning together and alone: Cooperative, competitive, and individualistic learning. Prentice-Hall, Inc, 1987.

[12] R. E. Slavin, “Cooperative learning," Rev. Educ. Res., vol. 50, no. 2, pp. 315-342, 1980.

[13] K. Cassidy, "Tuckman Revisited: Proposing a New Model of Group Development for Practitioners," J. Exp. Educ., vol. 29, no. 3, pp. 413-417, Sep. 2007, doi: $10.1177 / 105382590702900318$.

[14] B. W. Tuckman, "Developmental sequence in small groups.," Psychol. Bull., vol. 63, no. 6, p. 384, 1965.

[15] N. M. Tichy, Managing strategic change: Technical, political, and cultural dynamics, vol. 3. John Wiley \& Sons, 1983.

[16] S. Raue, S.-H. Tang, C. Weiland, and C. Wenzlik, "The GRPI model - an approach for team development," p. 14.

[17] I. M. Rubin, Task-oriented Team Development: Irwin M. Rubin, Mark S. Plovnick, Ronald E. Fry. McGraw-Hill, 1978.

[18] R. S. Carlock, "Assessment Tools for Developing and Leading Effective Teams," SSRN Electron. J., 2012, doi: 10.2139/ssrn.2055676.

[19] D. Goode and S. J. Wolf, "2 Conflict Management," Commun. Emerg. Med., 2019. 
[20] T. Karabiyik, A. Jaiswal, P. Thomas, and A. J. Magana, "Understanding the Interactions between the Scrum Master and the Development Team: A Game-Theoretic Approach," Mathematics, vol. 8, no. 9, Art. no. 9, Sep. 2020, doi: 10.3390/math8091553.

[21] R. Tartell, "Understand Teams by Using the GRPI Model | Training Magazine." https://trainingmag.com/trgmag-article/understand-teams-using-grpi-model/ (accessed Dec. 21, 2020).

[22] C.-W. Sheng, Y.-F. Tian, and M.-C. Chen, "Relationships Among Teamwork Behavior, Trust, Perceived Team Support, and Team Commitment," Soc. Behav. Personal. Int. J., vol. 38, no. 10, pp. 1297-1305, Nov. 2010, doi: 10.2224/sbp.2010.38.10.1297.

[23] H. Duckworth, "How TRW automotive helps global virtual teams perform at the top of their game," Glob. Bus. Organ. Excell., vol. 28, no. 1, pp. 6-16, 2008.

[24] S. Burgess and H. H. Sievertsen, "Schools, skills, and learning: The impact of COVID-19 on education," VoxEU.org, Apr. 01, 2020. https://voxeu.org/article/impact-covid-19-education (accessed Dec. 21, 2020).

[25] N. Kapasia et al., "Impact of lockdown on learning status of undergraduate and postgraduate students during COVID-19 pandemic in West Bengal, India," Child. Youth Serv. Rev., vol. 116, p. 105194, Sep. 2020, doi: 10.1016/j.childyouth.2020.105194.

[26] G. Di Pietro, F. Biagi, P. Costa, Z. Karpinski, and J. Mazza, "The likely impact of COVID-19 on education: Reflections based on the existing literature and recent international datasets," JT Rep. Ed, 2020.

[27] J. S. Radcliffe et al., "Moving online: roadmap and long-term forecast," Anim. Front., vol. 10, no. 3, pp. 36-45, Jul. 2020, doi: 10.1093/af/vfaa027.

[28] J. W. Creswell and V. L. P. Clark, Designing and conducting mixed methods research. Sage publications, 2017.

[29] V. Venkatesh, S. A. Brown, and H. Bala, "Bridging the qualitative-quantitative divide: Guidelines for conducting mixed methods research in information systems," MIS Q., pp. 2154, 2013.

[30] M. Syed and S. C. Nelson, "Guidelines for Establishing Reliability When Coding Narrative Data," Emerging Adulthood, vol. 3, no. 6, pp. 375-387, Dec. 2015, doi: $10.1177 / 2167696815587648$.

[31] V. Braun and V. Clarke, "Using thematic analysis in psychology," Qualitative Research in Psychology, vol. 3, no. 2, pp. 77-101, Jan. 2006, doi: 10.1191/1478088706qp063oa 